\title{
Characterization of stem, stripe and leaf rust resistance in Tajik bread wheat accessions
}

\author{
Mahbubjon Rahmatov (iD - Munira Otambekova - Hafiz Muminjanov • \\ Matthew N. Rouse • Mogens S. Hovmøller · Kumarse Nazari • Brian J. Steffenson • \\ Eva Johansson
}

Received: 11 May 2018/Accepted: 12 February 2019/Published online: 20 February 2019

(C) The Author(s) 2019

\begin{abstract}
Stem rust [causal organism: Puccinia graminis f. sp. tritici $(P g t)]$, stripe rust [Puccinia striiformis f. sp. tritici (Pst)], and leaf rust [Puccinia triticina $(P t)]$ are important fungal diseases of wheat in Central Asia and worldwide. Therefore, identification of seedling and adult plant resistance (APR) genes is of major importance for the national wheat breeding program in many countries. The objectives of this study were to identify genes that confer seedling and APR resistances in widely grown wheat cultivars, landraces and advanced lines from Tajikistan. A total of 41 wheat accessions were inoculated with eleven races of $P g t$, twelve races of $P s t$ and nine races of $P t$ for postulation of $S r$ (stem rust), $\mathrm{Yr}$ (yellow or stripe rust), and $\mathrm{Lr} \operatorname{Lr}$ (leaf rust) resistance genes at the seedling stage. In addition, all of the accessions were tested in field trials for the response to stem rust and stripe rust. Genes for seedling stem rust resistance (i.e.
\end{abstract}

M. Rahmatov $(\varangle) \cdot$ E. Johansson

Department of Plant Breeding, Swedish University of Agricultural Sciences, PO Box 101, SE-23053 Alnarp, Sweden

e-mail: mahbubjon@gmail.com

M. Otambekova $\cdot$ H. Muminjanov

Tajik Agrarian University, 146, Rudaki Ave.,

734017 Dushanbe, Tajikistan

M. N. Rouse

Cereal Disease Laboratory, United States Department of Agriculture-Agricultural Research Service, St. Paul, MN 55108, USA
Sr5, Sr6, Sr11, Sr31, and Sr38), stripe rust resistance ( $\mathrm{Yr} 9, \mathrm{Yr} 17$, and $\mathrm{Y27}$ ), and leaf rust resistance ( $\mathrm{Lrl6}$ and Lr26) were postulated in the Tajik wheat. The presence of the pleiotropic APR genes Sr2/Yr30/ Lr27 (associated with pseudo-black chaff phenotype) and $L r 34 / Y r 18 / S r 57$ (associated with leaf tip necrosis phenotype), and also $\operatorname{Lr} 37$ were assessed in the field and confirmed with linked molecular markers. In most of the wheat accessions, resistance genes could not be postulated because their infection types did not match the avirulence or virulence profile of the Pgt, Pst and $P t$ races tested. Six, seven, and nine accessions were identified that likely possess new genes for resistance to stem rust, stripe rust, and leaf rust, respectively, which have not been described previously. The research demonstrates the presence of effective seedling resistance and APR genes in widely grown wheat accessions that could facilitate further rust

\footnotetext{
M. S. Hovmøller

Department of Agroecology, Aarhus University,

Flakkebjerg, 4200 Slagelse, Denmark

K. Nazari

Regional Cereal Rust Research Center, Aegean

Agricultural Research Institute, P.K. 9, Menemen, Izmir, Turkey

M. N. Rouse · B. J. Steffenson

Department of Plant Pathology, University of Minnesota, St. Paul, MN 55108, USA
} 
resistance breeding in the national wheat breeding program in Tajikistan.

Keywords Gene postulation - Molecular marker · Resistance gene $\cdot$ Triticum aestivum

\section{Introduction}

Bread wheat (Triticum aestivum L., $2 n=6 x=42$, $17 \mathrm{~Gb}$, BBAADD genome) is one of the most important and widely cultivated food crops, contributing substantially to the daily nutrition and food security of a large proportion of the world's population (Shiferaw et al. 2013). Unfortunately, many abiotic and biotic stresses limit wheat production across the globe. Among the most important biotic stresses of wheat are the three rust diseases, namely stem rust [caused by Puccinia graminis f. sp. tritici Erikss. \& E. Henning (Pgt)], stripe rust [Puccinia striiformis Westend. f. sp. tritici Eriks. (Pst)], and leaf rust [Puccinia triticina Eriks. $(P t)]$. Since ancient times, these rust diseases have caused many epidemics, resulting in significant and widespread crop losses (Kolmer 2005; Hovmøller et al. 2011; Szabo et al. 2014). Stem rust and stripe rust can cause complete crop loss, and losses due to leaf rust can be as high as 70\% (Chen 2005; Huerta-Espino et al. 2011; Singh et al. 2015). In recent epidemics, yield losses ranging from 20 to $100 \%$ were reported for these three rust diseases in wheat growing regions worldwide (Huerta-Espino et al. 2011; Wellings 2011; Singh et al. 2015).

In Tajikistan, bread wheat is the most important food crop with respect to national food security (FAO 2015) but is constantly threatened by these three rust diseases. Epidemics of stripe rust occurred in 1952, 1958, 1966, 1997, 1998, 2003, 2010, and 2016, resulting in significant yield losses across the country (Eshonova et al. 2005; Rahmatov et al. 2011, 2012). Stem rust occurs mainly in the mountainous areas (Pett et al. 2005); however, when favorable environmental conditions prevail, the disease is capable of destroying the grain yield of wheat crops across all agroecological zones of Tajikistan. Leaf rust is more variable with respect to its impact on wheat in the country (Eshonova et al. 2005; Rahmatov et al. 2012).

Deployment of host genetic resistance is considered the most effective and low-cost management strategy for rust diseases, particularly in developing countries (Ellis et al. 2014). To control these rust diseases in Tajikistan, the national wheat breeding program has developed several rust resistant wheat cultivars by utilizing advanced breeding lines from the International Winter Wheat Improvement Program and Centro Internacional de Mejoramiento de Maíz y Trigo (CIMMYT). Genetic resistance to rust diseases has been broadly categorized into "seedling resistance," which is often conferred by single genes with major phenotypic effects across all growth stages of the plant (Flor 1971), and "adult plant resistance" (APR), which is often conferred by multiple genes with more subtle phenotypic effects during the later ontogenetic stages of plant development (Knott 1989). In selecting and breeding for rust resistance, seedling and adult plant phenotyping assays are routinely performed along with molecular marker assays if available for specific resistance genes (Juliana et al. 2017). One of the greatest challenges in breeding for rust resistance in wheat is the genetic variability of the rust pathogens. The virulence diversity of the three rust pathogens in Central Asia is high, particularly in Tajikistan (Kolmer and Ordoñez 2007; Berlin et al. 2015; Ali et al. 2017). For example, the first time Pst virulence was found for the yellow rust $(Y r)$ resistance genes of $\mathrm{Yrl}, \mathrm{Yr} 4+, \mathrm{Yr} 3 \mathrm{~N}, \mathrm{Yr} 9, \mathrm{Yr} 10, \mathrm{Yr} 17$ and $\mathrm{Yr} 27$ in Central Asia was in Tajikistan (Yahyaoui et al. 2012a, b). Eight barberry species have been reported in Tajikistan (Davlatov and Baikova 2011), which may play a role in disease epidemics and pathogen variation in the country since these species could potentially serve as alternate hosts for both Pgt and Pst.

Currently, more than 70 stem rust $(\mathrm{Sr})$ resistance genes, 65 yellow rust $(\mathrm{Yr})$ resistance genes and 79 leaf rust $(L r)$ resistance genes, including those with minor effects have been cataloged (McIntosh et al. 2017). Widely deployed cultivars with effective resistance genes can suffer yield losses when new, virulent races of the stem, stripe, and leaf rust pathogens emerge, leading to the "boom and bust" cycle of plant breeding (Pretorius et al. 2000; Huerta-Espino et al. 2011; Wellings 2011; Solh et al. 2012). Some of the most widely used and important resistance genes in wheat include Sr13, Sr24, Sr31, Sr36, Sr38, SrTmp and $\operatorname{Sr} 1 R S^{\text {Amigo }}$ for stem rust, the $\operatorname{Yr} 2, \operatorname{Yr} 6, \operatorname{Yr} 7, \operatorname{Yr} 8, \operatorname{Yr} 9$, $\mathrm{Yr} 17$ and $\mathrm{Yr} 27$ for stripe rust, and $L r 9, L r 14 a, L r 16$, $L r 17 a, L r 24, L r 26$ and $L r 39$ for leaf rust all of which 
have now been overcome by newly detected pathogen races (Huerta-Espino et al. 2011; Singh et al. 2015; Ali et al. 2017). The lack of knowledge regarding the presence of major effect seedling and minor effect APR resistance genes in Tajik wheat germplasm makes it difficult to make informed decisions with respect to breeding for stable resistance in the national wheat breeding program. Therefore, the aims of this study were to (1) evaluate Tajik wheat accessions for seedling resistance and postulate the presence of underlying $S r, Y r$ and $L r$ genes; (2) identify the presence of gene(s) conferring APR to the three rust diseases; and (3) verify the presence of resistance genes postulated by available molecular markers.

\section{Materials and methods}

Plant and pathogen materials

A total of twenty-nine wheat cultivars, seven advanced breeding lines, and five landraces were used in the present study and tested for response to the three rusts. These wheat accessions were provided by the national wheat breeding program in Tajikistan. The pedigree and origin of the materials are given in Table 1. In addition, differential wheat accessions with characterized resistance genes for stem rust (Jin et al. 2007), stripe rust (Hovmøller et al. 2017), and leaf rust (Kolmer and Hughes 2013) were also included to facilitate the gene postulations. Eleven $P g t$, twelve $P s t$ and nine $P t$ races with different virulence/avirulence combinations and geographic origins were used (Tables 2, 3 and 4).

\section{Seedling rust resistance assays}

Seedling resistance assays to stem rust and leaf rust were conducted at the United States Department of Agriculture-Agricultural Research Service-Cereal Disease Laboratory (USDA-ARS-CDL) and the University of Minnesota in St. Paul, USA. Five seeds of each wheat genotype were included for each rust assay. The seeds were planted in pots containing vermiculite (Sun Gro Horticulture), watered daily, and fertilized with 20-20-20 NPK soluble fertilizer (Spectrum Group, St. Louis). Stored urediniospores of the stem and leaf rust pathogens were removed from $\mathrm{a}-80{ }^{\circ} \mathrm{C}$ freezer, heat-shocked at $45^{\circ} \mathrm{C}$ for $15 \mathrm{~min}$ and placed in a rehydration chamber for 2 to $4 \mathrm{~h}$ maintained at $80 \%$ relative humidity by a $\mathrm{KOH}$ solution, and then suspended in a lightweight mineral oil (Soltrol $170^{\circledR}$ Chevron Phillips Chemical Company LP, Woodlands, TX 77380) within gelatin capsules (size 00). Then, urediniospores were inoculated onto 8-10 day-old seedlings of the different accessions at the first leaf stage. Seedling resistance assays for stem rust were done according to the methods of Rouse et al. (2011) and those for leaf rust were done according to Oelke and Kolmer (2004). Infection types were scored 14 days after inoculation using a 0-4 scale (Stakman et al. 1962; Long and Kolmer 1989). Seedling resistance to Pgt race TKTTF (bulk collection from Turkey) was carried out at the Regional Cereal Rust Research Center (RCRRC), located at the Aegean Agricultural Research Institute, International Center for Agricultural Research in the Dry Areas (ICARDA) in Izmir, Turkey (Rahmatov et al. 2016). The methods used for this test were similar to those used for the other races, the exception being that fresh urediniospores collected from plants in the field were used instead of frozen urediniospores. Ten-day-old seedlings with the first leaves fully expanded were inoculated with race TKTTF according to Rahmatov et al. (2016).

All accessions were evaluated for seedling stripe rust resistance at the Global Rust Reference Center (GRRC) at Aarhus University in Flakkebjerg, Denmark and at the RCRRC. For these evaluations, ten seeds were sown in pots containing a mixture of peat moss and soil. Inoculations with races of $P s t$ were carried out on 14-day-old seedlings when the second leaves were fully expanded. For inoculations completed at the GRRC and RCRRC, Pst urediniospores were suspended in Novec Fluid ( $3 \mathrm{M} \mathrm{Novec}^{\mathrm{TM}} 7100$ Engineered Fluid) and lightweight mineral oil, respectively (Rahmatov et al. 2017). After inoculation, plants were moved to a dark chamber at $100 \% \mathrm{RH}$ at $10{ }^{\circ} \mathrm{C}$ for $24 \mathrm{~h}$ for the infection period. Thereafter, plants were incubated in a greenhouse at $18{ }^{\circ} \mathrm{C}$ for $18 \mathrm{~h}$ during the day and $12{ }^{\circ} \mathrm{C}$ for $6 \mathrm{~h}$ during the night, protocols routinely used at both the GRRC and RCRRC (Hovmøller et al. 2017; Rahmatov et al. 2017). After 16 days of incubation, stripe rust infection types were scored using a $0-9$ scale as described by McNeal et al. (1971). 
Table 1 List of wheat accessions evaluated in this study

\begin{tabular}{|c|c|c|c|c|c|}
\hline \# & Accession & Pedigree & Origin & Type & $\begin{array}{l}\text { Accession } \\
\text { status }\end{array}$ \\
\hline 1 & Navruz & (S)MIRONOVSKAYA-YUBILEINAYA & Tajikistan & Facultative & Cultivar \\
\hline 2 & Sarvar & $\begin{array}{l}\text { CHEN/AEGILOPS SQUARROSA (TAUS)//BCN/3/ } \\
\text { BAV92 }\end{array}$ & ESWYT25 & Spring & Cultivar \\
\hline 3 & Vahdat & VORONA/CNO79//KAUZ/3/MILAN & ESWYT25 & Spring & Cultivar \\
\hline 4 & Yusufi & SOROCA & ESWYT25 & Spring & Cultivar \\
\hline 5 & Isfara & SW89.5181/KAUZ & ESWYT25 & Spring & Cultivar \\
\hline 6 & Alex & PAYNE(PYN)/(BAU)BAGULA & 1WWEERYT & Facultative & Cultivar \\
\hline 7 & Oriyon & $\begin{array}{l}\text { NORD-DESPREZ/VG-9144//KALYANSONA/ } \\
\text { BLUEBIRD/3/YACO/4/VEERY-5 }\end{array}$ & N.A. & Facultative & Cultivar \\
\hline 8 & Sadokat & JUPATECO-73/BLUEJAY//URES-81 & Mexico & Spring & Cultivar \\
\hline 9 & Ziroat-70 & N.A. & N.A. & Facultative & Cultivar \\
\hline 10 & Norman & $\begin{array}{l}\text { OR-F-1-158/(FDL)FUNDULEA//(BLO) } \\
\text { BOLILLO/3/SHI-4414/CROW }\end{array}$ & 5FAWWON & Facultative & Cultivar \\
\hline 11 & Somoni & N.A. & N.A. & Facultative & Cultivar \\
\hline 12 & Tacicar & TR.AE/SPARROW//ZARAPITIN & 5FAWWON & Facultative & Cultivar \\
\hline 13 & Ormon & NWT/3/TAST/SPRW//TAW12399.75 & 8FAWWON & Facultative & Cultivar \\
\hline 14 & Iqbol & RUSALKA,BGR/CA-8055//CHAM-6 & N.A. & Facultative & Cultivar \\
\hline 15 & Starshina & COLT/SPARTANKA & Russia & Winter & Cultivar \\
\hline 16 & Shokiri & SHARK/F-4105-W-2-1 & 5WWEERYT & Facultative & Cultivar \\
\hline 17 & Fayzbaksh & TAM200/KAUZ & 6WWEERYT & Facultative & Cultivar \\
\hline 18 & Nurbakhsh & PRINA/STAR & N.A. & Facultative & Cultivar \\
\hline 19 & BASRIBEY-95 & JUPATECO-73/(SIB)BLUEJAY//URES-81 & Turkey & Facultative & Cultivar \\
\hline 20 & Jagger & KS-82-W-418/STEPHENS & USA & Winter & Cultivar \\
\hline 21 & Kaboi Panjakent & N.A. & Tajikistan & Facultative & Landrace \\
\hline 22 & Surkhaki 5 & N.A. & Tajikistan & Spring & Landrace \\
\hline 23 & Zafar & N.A. & Tajikistan & Facultative & Cultivar \\
\hline 24 & Steklovidnaya-24 & $\begin{array}{l}\text { BOGARNAYA-56/TEPLOKL } \\
\text { YUCHENSKAYA-2//ROSTOVCHANKA }\end{array}$ & Kazakhstan & Winter & Cultivar \\
\hline 25 & $\begin{array}{l}\text { SIETE-CERROS- } \\
66\end{array}$ & PENJAMO-62(SIB)/GABO-55 & Mexico & Spring & Cultivar \\
\hline 26 & Krasnodarskaya-99 & $\begin{array}{l}\text { LUTESCENS-2665-G-10233/ERYTHROSPER } \\
\text { MUM-4695-h-449//LUTESCENS-2621-h-24-82 }\end{array}$ & Russia & Winter & Cultivar \\
\hline 27 & Jayhun & N.A. & Turkey & Facultative & Cultivar \\
\hline 28 & IZ-80 & KAUZ * 2/CHEN//BCN/3/MILAN & & Facultative & Cultivar \\
\hline 29 & AIKT-20 & CBRD/KAUZ & & Facultative & Cultivar \\
\hline 30 & N.A. & OTUS TOBA 97 & & Facultative & Advanced line \\
\hline 31 & N.A. & PASTOR/3/VORONA & & Facultative & Advanced line \\
\hline 32 & N.A. & CMN82A.1294/2* & & Facultative & Advanced line \\
\hline 33 & N.A. & HUAVUN INIA & & Facultative & Advanced line \\
\hline 34 & Trakua Hatti & N.A. & Turkey & Facultative & Advanced line \\
\hline 35 & Murodi-2013 & CHEN/AE.SQ//WEAVER/3/SSERI1 & 27ESWYT & Spring & Cultivar \\
\hline 36 & N.A. & CHEN/AE.SQ//WEAVER/3/PASTOR & 27ESWYT & Spring & Advanced line \\
\hline 37 & Ganj & NAC/TH.AC//3* PVN/3/MIRLO/BUC/4/2 *vPASTOR & 27ESWYT & Spring & Cultivar \\
\hline 38 & N.A. & NAC/TH.AC//3 * PVN/3/MIRLO/BUC/4/2 * PASTOR & 27ESWYT & Spring & Advanced line \\
\hline
\end{tabular}


Table 1 continued

\begin{tabular}{|c|c|c|c|c|c|}
\hline$\#$ & Accession & Pedigree & Origin & Type & $\begin{array}{l}\text { Accession } \\
\text { status }\end{array}$ \\
\hline 39 & Safedaki Pomir & N.A. & Tajikistan & Spring & Landrace \\
\hline 40 & $\begin{array}{l}\text { Safedaki } \\
\text { Ishkoshim }\end{array}$ & N.A. & Tajikistan & Spring & Landrace \\
\hline 41 & Babilo Pomir & N.A. & Tajikistan & Spring & Landrace \\
\hline
\end{tabular}

N.A. not available, ESWYT elite spring wheat yield trial, FAWWON facultative and winter wheat observation nursery, WWEERYT winter wheat eastern european regional yield trial

Assessment of field response to stem rust and stripe rust

Adult plant stem rust responses were evaluated under field conditions at the Kenyan Agricultural and Livestock Research Organization in Njoro (2010 and 2011), at the RCRRC in Izmir (2014) and at the University of Minnesota in St. Paul (2014). In Tajikistan, the wheat accessions were exposed to naturally occurring races of Pst during the growing season of 2010. The stripe rust-infected leaves were collected in Tajikistan and sent to the GRRC for race analysis (Hovmøller et al. 2017), and the race TJ01a/ 10 was detected and subsequently used at the seedling resistance test. To provide sufficient stripe rust infection in the nurseries at RCRRC, mixtures of susceptible wheat cultivars were used as spreader rows surrounding and between the plots (Rahmatov et al. 2017). In Njoro and Minnesota, urediniospores of $P g t$ (TTKSK + TTKST, and MCCFC) were needle-injected (i.e. injecting urediniospores directly into the stems of susceptible spreader plants) at the tillering, booting and heading stages. Additionally, direct foliar inoculations were made on the spreader rows using a urediniospore/oil suspension (Rahmatov et al. 2016). In Izmir, the spreader rows were inoculated five times at the tillering, booting and heading stages by dusting a mixture of fresh urediniospores of Pgt (TKTTF) and Pst (TK34/11) together with talcum powder. After inoculation, the nurseries in Njoro and Izmir were mist-irrigated three times per day (i.e. morning, afternoon and evening) to ensure a moist environment and thereby enhance stem and stripe rusts development. The adult plant response to stem and stripe rust were assessed between growth stages 50-90 (Zadoks et al. 1974). Disease severity was assessed using the modified Cobb scale (Peterson et al. 1948) and adult plant infection types were rated according to Roelfs et al. (1992). The presence of the pseudo-black chaff $(P B C)$ and leaf tip necrosis $(L T N)$ phenotypes were assessed using 0-4 scale in all field trials (Juliana et al. 2015).

Molecular marker analysis

Total genomic DNA was isolated from the leaves of 10 day-old seedlings according to Edwards et al. (1991) with some slight modifications. The molecular markers XcsSr2, Xgwm533 and wMASO00005 for Sr2/ Yr30/Lr27 (Spielmeyer et al. 2003; Mago et al. 2011), Xcfd43 for Sr6 (Tsilo et al. 2009) Xwmc364 for $Y r 2$ (Lin et al. 2005), Xscm 9 and Xiag95 for Sr31/Yr9/Lr26 (Saal and Wricke 1999; Mago et al. 2005), csLV34 and wMAS000003 for $L r 34 / Y r 18 / S r 57$ (Lagudah et al. 2006), and VENTRIUP/LN2 for Sr38/Yr17/Lr37 (Helguera et al. 2003) were assessed. The PCR assays were conducted according to Rahmatov et al. (2016).

\section{Results}

Stem rust seedling response assays

A majority of the wheat accessions showed seedling resistance towards the Pgt races of RKQQC, QTHJC, TPMKC, BCCBC, and MCCFC with infection types (ITs) ranging from 0 to $2+$ (Table 5). A lower proportion of the wheat accessions showed seedling resistance towards the more widely virulent $P g t$ races of TTTTF, TTKSK, TTTSK, TTKST, TRTTF and TKTTF (Table 5). The resistance gene Sr5 was postulated in Navruz and Steklovidnaya-24 based on its resistance reaction to race BCCBC (Table 5). Sr6 and $\mathrm{Srll}$ were postulated in Siete-Cerros-66 based on its resistance reactions to races RKQQC, TPMKC, TKTTF, MCCFC and BCCBC (Table 5). Resistance 


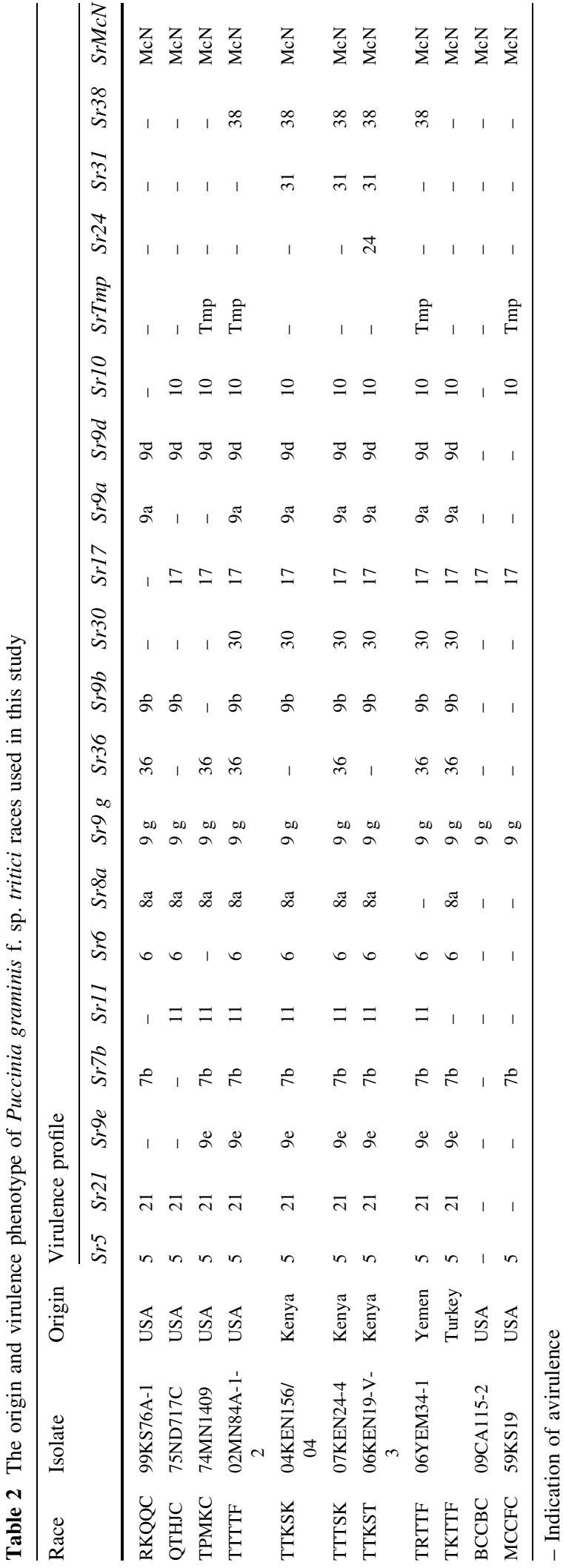

gene $\operatorname{Sr} 31$ was postulated in Alex, Sadokat, Ziroat-70 and Otus Toba97 based on their susceptible reactions to races TTKSK, TTTSK and TTKST (Table 5); and Sr38 in Jagger and IZ-80 based on their susceptible reactions to races TTTTF, TTKSK, TTTSK, TTKST and TRTTF (Table 5). The landraces of Kaboi Panjakent, Surkhaki-5, Jayhun, Safedaki Pomir, and Safedaki Ishkoshim were resistant to races TTKSK, TTTSK and TTKST (Table 5). Only Sarvar was highly resistant to all the tested races (Table 5). If any previously described resistance genes were present in this group of accessions, they could not be postulated because the resulting ITs did not match those of any differential accessions. Thus, these accessions either carry combinations of previously described genes or new resistance gene/s.

Stripe rust seedling response assays

Postulations for $Y r$ genes were conducted using 12 Pst races (Table 3). $\operatorname{Yr} 9$ and $\operatorname{Yr} 17$ were confirmed based on the stem rust gene postulations for $\mathrm{Sr} 31$ and $\mathrm{Sr} 38$ plus molecular markers because of their tight linkage with the respective genes within the 1BL.1RS wheatrye and 2NS/2AS translocations. These assays confirmed the presence of $Y r 9$ in Alex, Sadokat, Ziroat-70, and Otus Toba97 and $\operatorname{Yr} 17$ in Jagger and IZ-80 (Tables 6, 8). Because Alex, Sadokat, Ziroat-70, Otus Toba97, Jagger and IZ-80 were resistant to most of the Pst races used in this study, including those carrying virulence for $\mathrm{Yr} 9$ and $\mathrm{Yr} 17$, thus it was not possible to postulate genes based on their ITs to the 12 Pst races used in this study (Table 6). The $\mathrm{Yr} 27$ was confirmed in Isfara based on the $Y r 27$-virulent isolates AF87/12 and TR34/11 conferring ITs of 7 on Yr27 differential lines (Table 6). Sarvar, Fayzbakhsh, Otus Toba97, Vahdat, Oriyon, Sadokat and AIKT-20 were highly resistant (ITs 0-4) to all or nearly all races; thus, the genes they carry could not be postulated with the Pst races used in this study nor the molecular markers. These accessions carry combinations of previously described genes or new resistance gene/s (Table 6).

Leaf rust seedling response assays

For the leaf rust seedling evaluations, nine $P t$ races were used (Table 4). The number of resistant and susceptible accessions for each of the races is presented in Table 7. Lrl6 was postulated in Iqbol, 


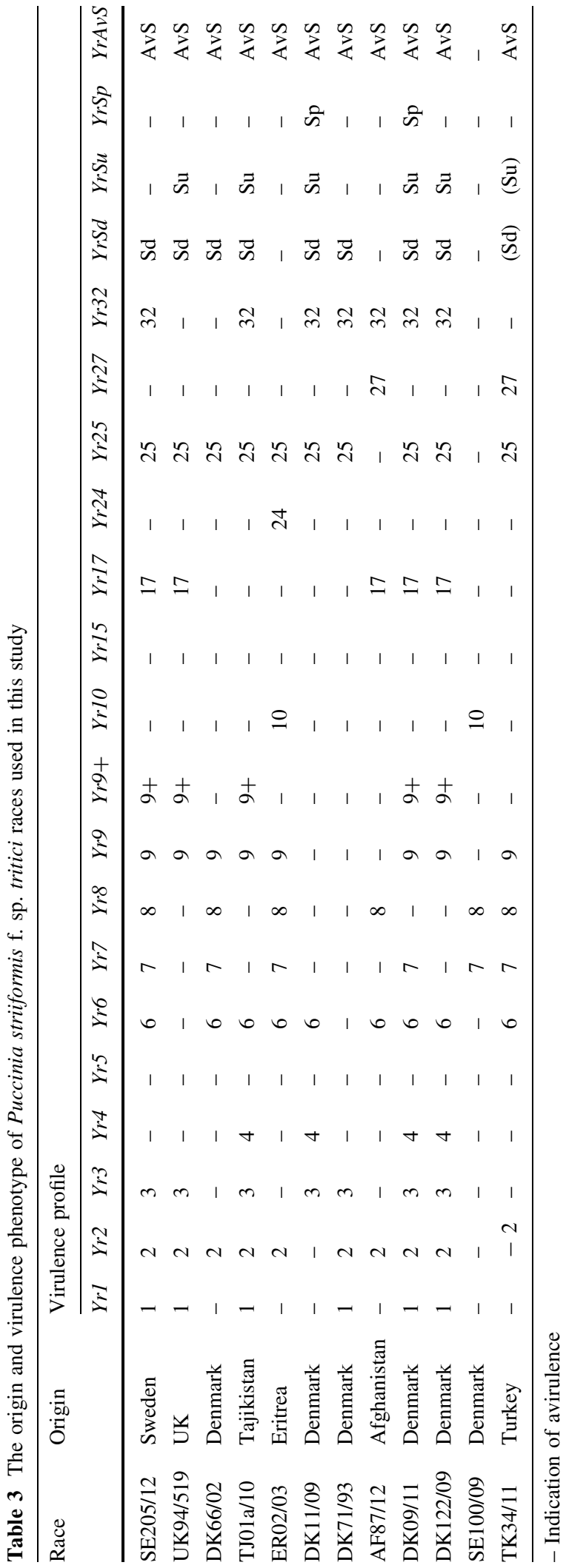

OTUS TOBA97, and HUAVUN INIA based on their susceptible reactions (ITs of $33+$ ) to race MHDSB (Table 7). Lr26 was postulated in Alex, Sadokat, and Ziroat-70 based on their susceptible reactions (ITs $33+$ ) to races KFBJG, MHDSB, and TCRKG and molecular markers (Tables 7,8 ). OTUS TOBA97 was resistant to all $P t$ races, except MHDSB (Table 7); therefore, the presence of $\operatorname{Lr} 26$ was confirmed based on the stem rust, stripe rust and molecular marker analysis (Tables 7, 8). Nine accessions (Sarvar, Vahdat, PRINA/STAR, Zafar, AIKT-20, PASTOR/3/ VORONA, CMN82A.1294/2*, Murodi-2013, and Ganj) likely carry combinations of previously described $L r$ genes or new $L r$ gene/s.

Field stem rust responses

For all of the stem rust field evaluations in Kenya, Turkey, and USA, a high level of disease pressure was attained as severities were $100 \%$ in susceptible controls. Some accessions showing no discernible seedling resistance exhibited high levels of APR in the field evaluations (Table 5). Thus, despite susceptibility at the seedling stage for TTKSK and TTKST, accessions PASTOR/3/VORONA/CN079 (10MSS), CMN82A.1294/2* (50MR) and HUAVUN INIA (40MR) against the $P g t$ race TTKSK + TTKST were exhibited APR during 2010 and 2011 in Njoro (Table 5). Furthermore, the accessions Vahdat, Somoni, Iqbol, Fayzbaksh, Kaboi Panjakent, and Surkhaki-5 exhibited disease severities of 5 to $40 \%$ with R to MR infection types, whereas Murodi-2013, Ganj, Krasnodarskaya-99, and Babilo Pomir had severities of 20 to $40 \%$ with MR-MS or MS infection types against race TKTTF in Izmir (Table 5). To race MCCFC in the USA, Navruz, Starshina, Basirbey, Kaboi Panjakent, Surkhaki-5, Steklovidnaya-24, Jayhun, Safedaki Pomir, and Safedaki Ishkoshim exhibited severities of 5 to $40 \%$ with RMR to MRMS and MS infection types (Table 5). Four accessions exhibited all stage resistance against race TTKSK + TTKST, thirteen against race TKTTF, and 32 against race MCCFC (Table 5). Thereby, these lines carry seedling resistance genes that are effective into the adult plant stage and to diverse races at three different field sites (Table 5). 
Table 4 The origin and virulence phenotype of Puccinia triticina races used in this study

\begin{tabular}{|c|c|c|c|c|c|c|c|c|c|c|c|c|c|}
\hline \multirow[t]{2}{*}{ Race } & \multirow[t]{2}{*}{ Origin } & \multicolumn{12}{|c|}{ Virulence profile } \\
\hline & & $\operatorname{Lrl}$ & $\operatorname{Lr} 2 a$ & $\operatorname{Lr} 2 c$ & $\operatorname{Lr} 3$ & $\operatorname{Lr} 9$ & Lrl6 & $\operatorname{Lr} 24$ & $\operatorname{Lr} 26$ & Lr3ka & Lr11 & $\operatorname{Lr} 17$ & $\operatorname{Lr} 30$ \\
\hline TDBJG & USA & 1 & $2 \mathrm{a}$ & $2 \mathrm{c}$ & 3 & - & - & 24 & - & - & - & - & - \\
\hline TFBJQ & USA & 1 & $2 \mathrm{a}$ & $2 \mathrm{c}$ & 3 & - & - & 24 & 26 & - & - & - & - \\
\hline TNRJJ & USA & 1 & $2 \mathrm{a}$ & $2 \mathrm{c}$ & 3 & 9 & - & 24 & - & $3 \mathrm{ka}$ & 11 & - & 30 \\
\hline MLDSD & USA & 1 & - & - & 3 & 9 & - & - & - & - & - & 17 & - \\
\hline MBDSB & USA & 1 & - & - & 3 & - & - & - & - & - & - & 17 & - \\
\hline TBBGG & USA & 1 & $2 \mathrm{a}$ & $2 \mathrm{c}$ & 3 & - & - & - & - & - & - & - & - \\
\hline KFBJG & USA & - & $2 \mathrm{a}$ & $2 \mathrm{c}$ & 3 & - & - & 24 & 26 & - & - & - & - \\
\hline MHDSB & USA & 1 & - & - & 3 & - & 16 & - & 26 & - & - & 17 & - \\
\hline TCRKG & USA & 1 & $2 \mathrm{a}$ & $2 \mathrm{c}$ & 3 & - & - & - & 26 & $3 \mathrm{ka}$ & 11 & - & 30 \\
\hline \multirow[t]{2}{*}{ Race } & \multirow[t]{2}{*}{ Origin } & \multicolumn{12}{|c|}{ Virulence profile } \\
\hline & & $\operatorname{LrB}$ & $\operatorname{Lr} 10$ & $\operatorname{Lr14a}$ & $\operatorname{Lr} 18$ & $\operatorname{Lr} 21$ & $\operatorname{Lr} 28$ & $\operatorname{Lr} 39$ & $\operatorname{Lr} 42$ & Lr3bg & $\operatorname{Lr} 14 b$ & $\operatorname{Lr} 20$ & $\operatorname{Lr} 23$ \\
\hline TDBJG & USA & - & 10 & $14 \mathrm{a}$ & - & - & 28 & - & - & - & $14 b$ & - & - \\
\hline TFBJQ & USA & - & 10 & $14 \mathrm{a}$ & - & 21 & 28 & - & - & - & $14 b$ & 20 & 23 \\
\hline TNRJJ & USA & - & 10 & $14 \mathrm{a}$ & - & - & 28 & 39 & - & - & $14 \mathrm{~b}$ & 20 & - \\
\hline MLDSD & USA & B & 10 & $14 \mathrm{a}$ & - & - & - & 39 & - & $3 b g$ & $14 b$ & 20 & 23 \\
\hline MBDSB & USA & B & 10 & $14 \mathrm{a}$ & - & - & - & - & - & $3 b g$ & $14 b$ & 20 & - \\
\hline TBBGG & USA & - & 10 & - & - & - & 28 & & - & $3 b g$ & $14 b$ & 20 & 23 \\
\hline KFBJG & USA & - & 10 & $14 \mathrm{a}$ & - & - & 28 & - & - & - & $14 b$ & 20 & 23 \\
\hline MHDSB & USA & B & 10 & $14 \mathrm{a}$ & - & - & - & - & - & $3 b g$ & $14 b$ & 20 & - \\
\hline TCRKG & USA & - & 10 & $14 \mathrm{a}$ & 18 & - & 28 & - & - & $3 b g$ & $14 \mathrm{~b}$ & 20 & - \\
\hline
\end{tabular}

- Indication of avirulence

Field stripe rust responses

Stripe rust APR was detected in the seedling-susceptible accessions of Vahdat, Isfara, and Ormon (severities of 10 to $20 \%$ with infection types of R to MR) and also in Tacikar and CMN82A.1294/2* (severities of 40 to $50 \%$ with MR-MS infection types) against Pst race TK34/11 (Table 6). Somoni and Tacikar also possess some APR as they exhibited a stripe rust severity of $40 \%$ with MS infection types against race TJ01a/10 in Tajikistan. A total of twenty-one and eighteen accessions had all-stage resistance as they were highly resistant at both the seedling and adult plant stages to Pst races TK34/11 and TJ01a/10 in Turkey and Tajikistan, respectively (Table 6). The rest of the wheat accessions were susceptible at the seedling and adult plant stages (Table 6).
Phenotypic assessments of $P B C$ and $L T N$ in the field

The presence of the $P B C$ and $L T N$ phenotypes were associated with the pleiotropic $S r 2 / Y r 30 / L r 27$ and Lr34/Yr18/Sr57 APR genes. The PBC phenotype (score of 2-3) was observed in 11 accessions, and the LTN phenotype (score of 2-3) was observed in 13 accessions in the field (Table 8).

Molecular marker analysis

The molecular markers Xscm 9 (220 bp), Xiag95 (1100 bp) and Xrems1303 (309 bp) indicated the presence of the $S r 31 / \mathrm{Yr} 9 / \mathrm{Lr} 26$ resistance genes in Alex, Sadokat, Ziroat-70, and OTUS TOBA 97. Marker Xcfd43 (215 bp) indicated the presence of Sr6 in SIETE-CERROS-66, and marker VENTRIUP/ $L N 2$ (262 bp) indicated the presence of the $\mathrm{Sr} 38 / \mathrm{Yr} 17 /$ Lr37 genes in Jagger and IZ-80. Marker Xgwm533 


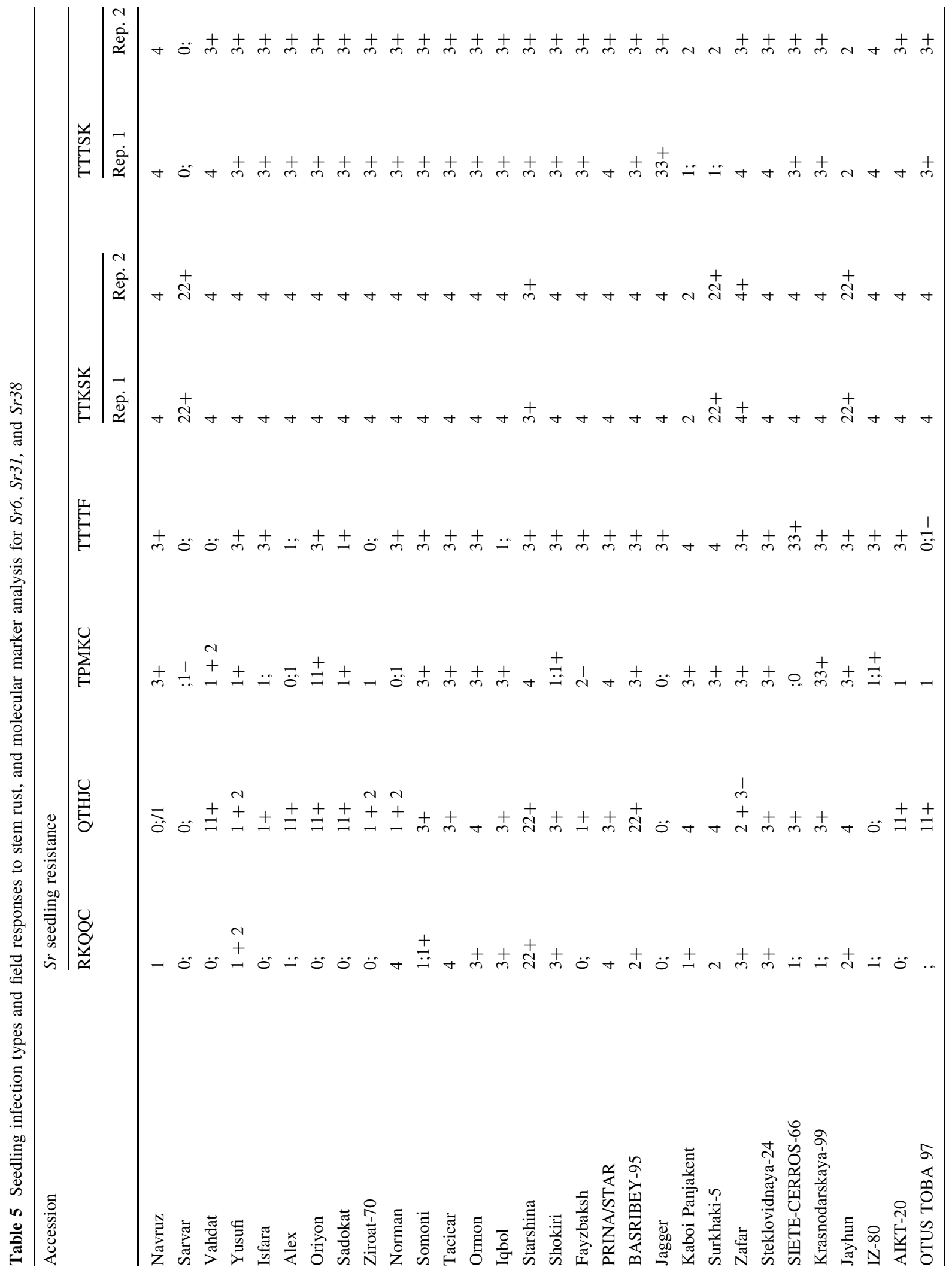




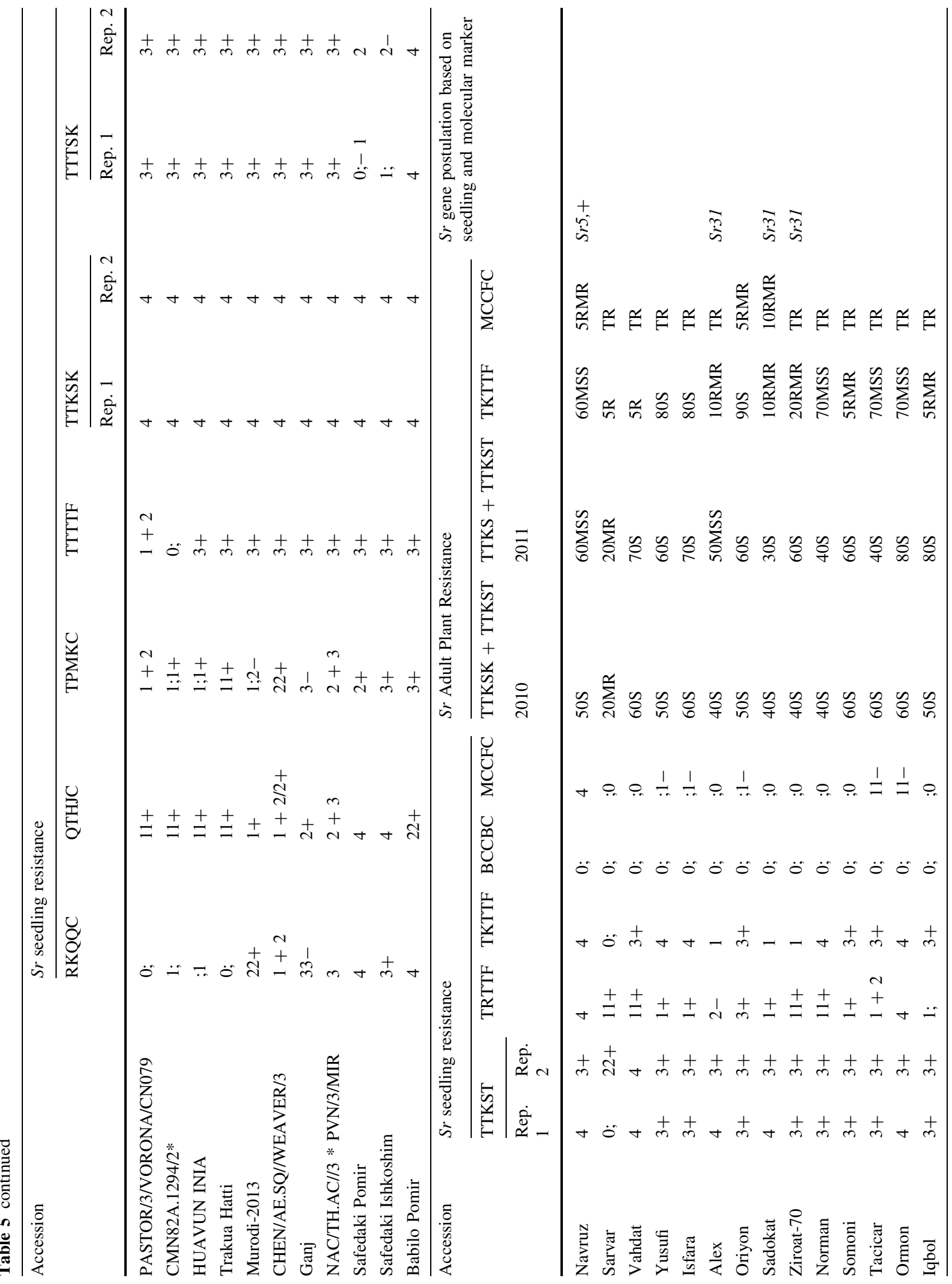




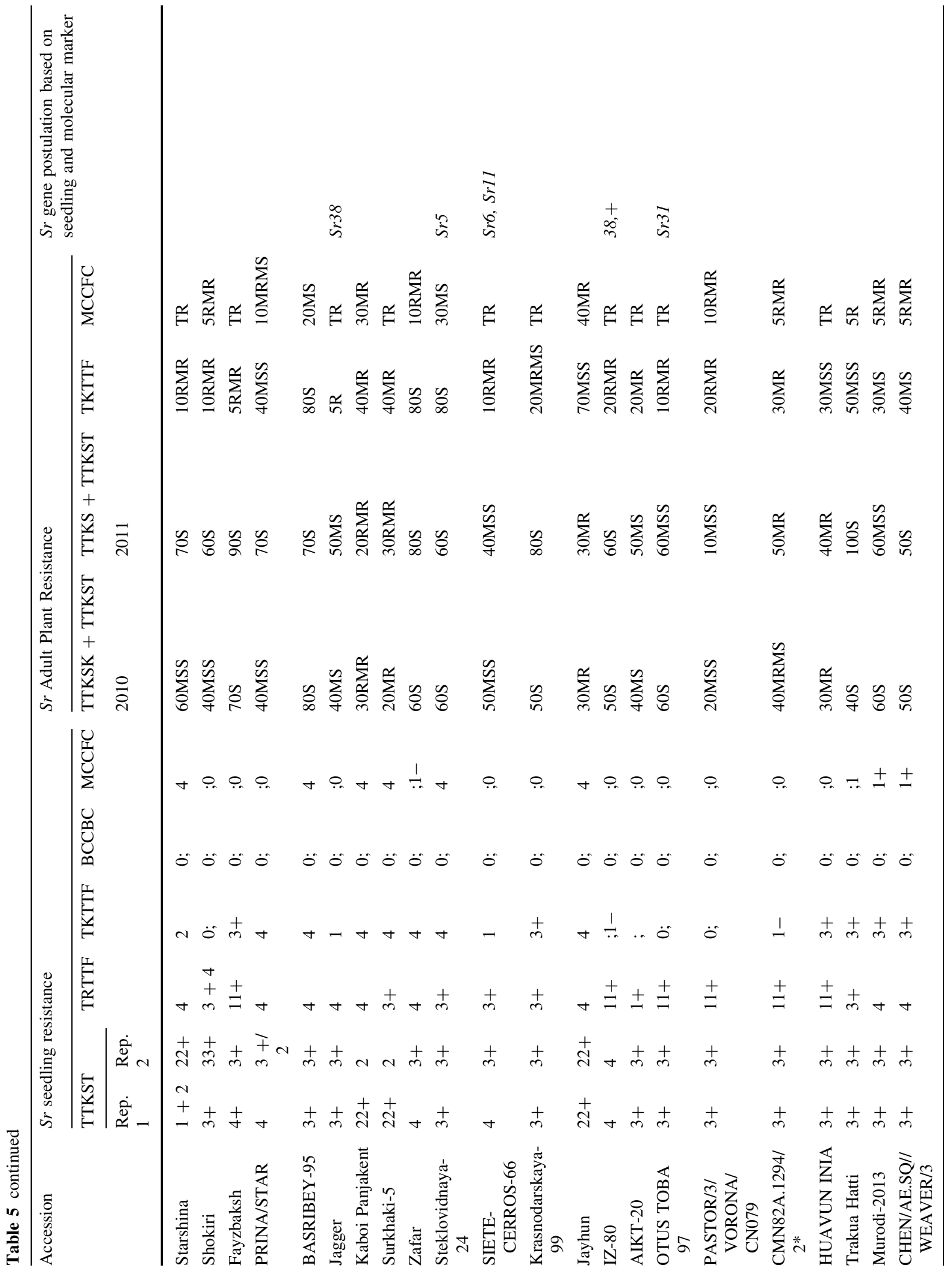




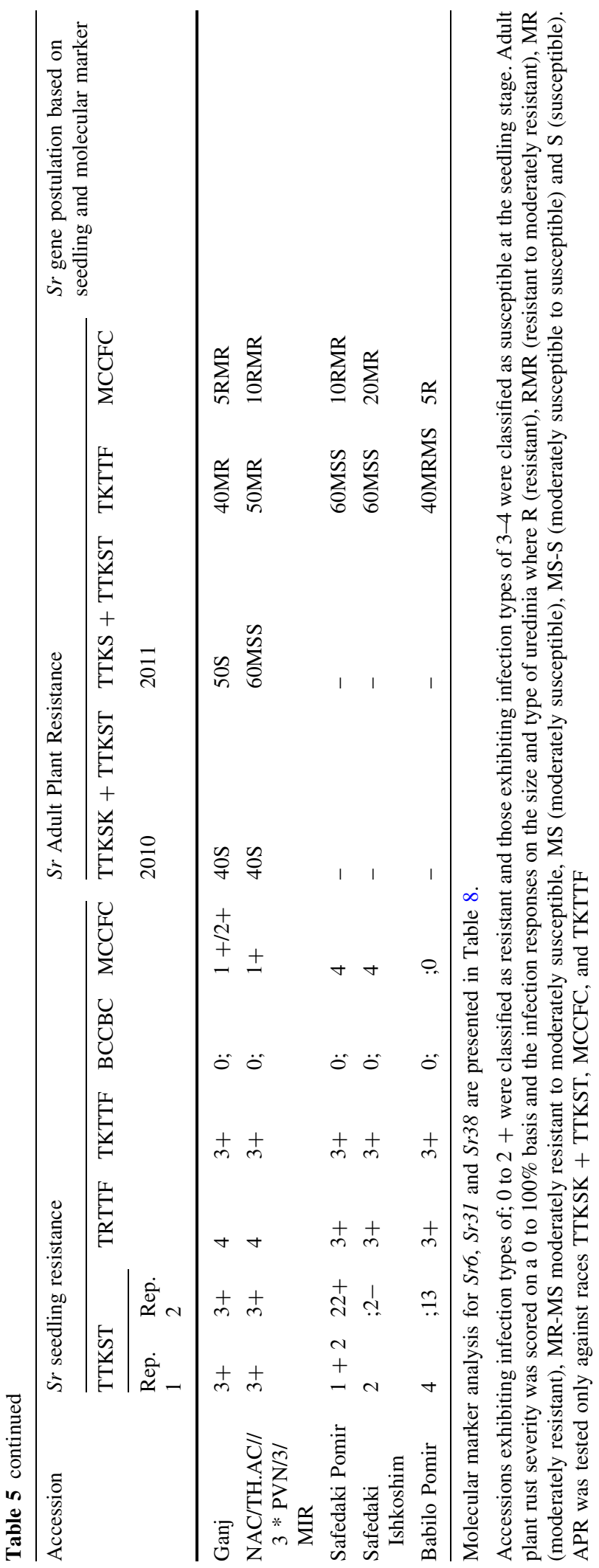




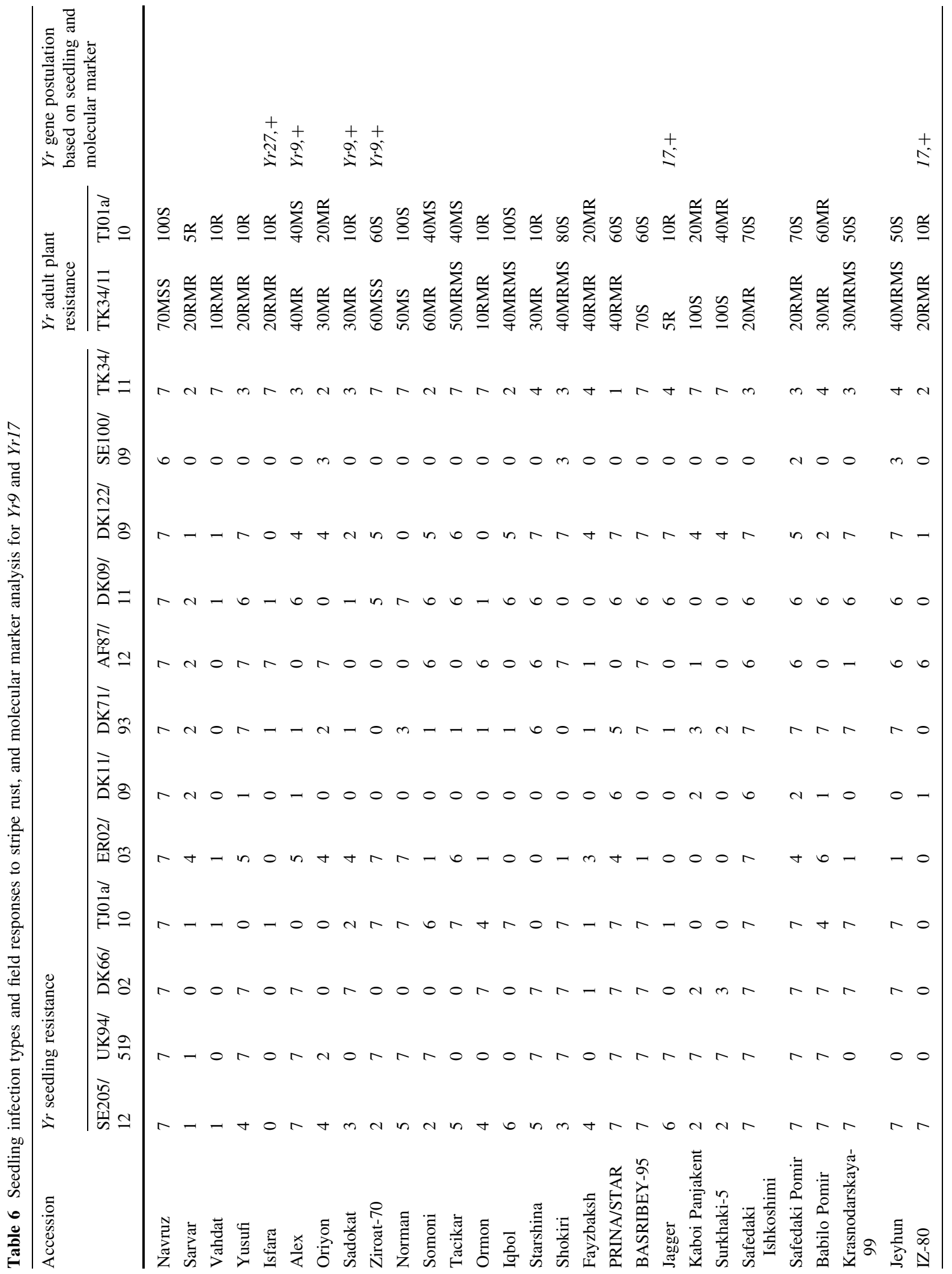




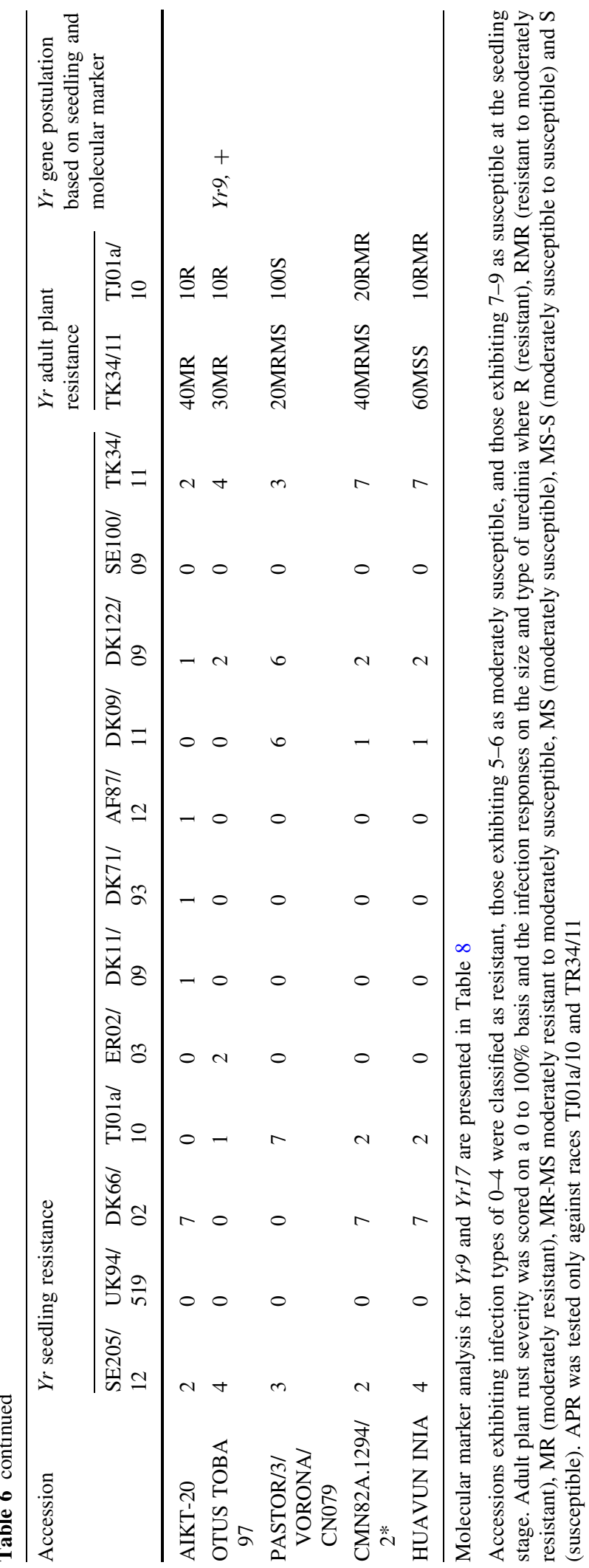


Table 7 Seedling infection types to leaf rust, and molecular marker analysis for Lr26

Accession $\quad L r$ seedling resistance

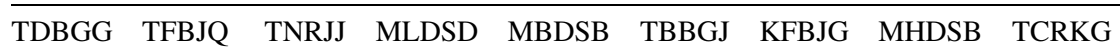

Lr gene postulation based on seedling and molecular marker

\begin{tabular}{|c|c|c|c|c|c|c|c|c|c|c|}
\hline Navruz & ;1- & 3 & $3+$ & 3 & $33+$ & $33+$ & $3+$ & $3+$ & $33+$ & \\
\hline Sarvar & 0 & 0 & ; & 3 & ; & ; & ; & ; & ; & \\
\hline Vahdat & ; & ; & ; & ; & ; & $; 1-$ & $32+$ & $11+$ & $; 1-$ & \\
\hline Yusufi & ; & ;12 & $; 1$ & $33+$ & ; & $; 1$ & $3+$ & ; & $; 1$ & \\
\hline Isfara & $; 1-$ & $33+$ & 3 & 3 & ; & $; 11+$ & $33+$ & $1+2$ & 12 & \\
\hline Alex & 0 & $; 1$ & ; & $11+$ & ; & $; 1-$ & $33+$ & $33+$ & $33+$ & $\operatorname{Lr} 26$ \\
\hline Oriyon & $; 1-$ & $; 1$ & 3 & $11+$ & $; 1+$ & ;12- & 3 & $3+$ & $33+$ & \\
\hline Sadokat & ; & $; 1-$ & ; & $1+$ & $1-$ & $; 1-$ & $2+3$ & 3 & $; 1$ & $\operatorname{Lr} 26$ \\
\hline Ziroat-70 & ; & $; 12$ & ; & $22+$ & $11+$ & $; 1-$ & $2 ; 3$ & 3 & $; 1$ & $\operatorname{Lr} 26$ \\
\hline Norman & $; 1-$ & 3 & $3+$ & $33+$ & 3 & $; 1$ & $3+$ & $33+$ & $3+$ & \\
\hline Somoni & $2+$ & $33+$ & 3 & $22+$ & $11+$ & $33+$ & $22+$ & $2+$ & $33+$ & \\
\hline Tacicar & $; 1-$ & ;12 & 3 & $33+$ & $; 1-$ & $; 11+$ & $33+$ & $22+$ & $33+$ & \\
\hline Ormon & ; & ${ }^{; 1 /} 22+$ & $33+$ & 3 & 12 & 3 & 3 & $33+$ & $; 11+$ & \\
\hline Iqbol & $; 12$ & 2 & $; 12$ & $11+$ & $; 1$ & $11+$ & $11+$ & $33+$ & $11+2-$ & Lr16 \\
\hline Starshina & $; 1-$ & 3 & 3 & 3 & $22+$ & 3 & $3+$ & $3+$ & $33+$ & \\
\hline Shokiri & ; & $; 1$ & ; & $22+$ & $1+$ & 3 & $22+$ & $33+$ & $; 1$ & \\
\hline Fayzbaksh & $33+$ & $22+$ & $3+$ & $; 1$ & ; & ; & ; & $3+$ & $; 1$ & \\
\hline PRINA/STAR & $; 1-$ & $2+3$ & 1 & $; 1$ & $11+$ & $1+2$ & $; 1-$ & $3+$ & $; 11+$ & \\
\hline BASRIBEY-95 & $; 1-$ & $33+$ & $33+$ & $2+$ & $1+$ & $; 11+$ & $3+$ & $; 1-$ & $11+$ & \\
\hline Jagger & $3+$ & $3+$ & $2+$ & $2+$ & $11+$ & $; 1$ & $33+$ & $33+$ & $1+2$ & \\
\hline Kaboi Panjakent & $3+$ & $3+$ & $3+$ & $3+4$ & $3+$ & $3+4$ & $3+4$ & $3+4$ & $3+$ & \\
\hline Surkhaki 5 & $3+$ & $33+$ & $3+$ & $3+$ & $3+4$ & $3+4$ & $3+4$ & $3+4$ & $3+$ & \\
\hline Zafar & $; 1-$ & $; 1+$ & ; & $11+$ & $; 1$ & $; 1-$ & $; 1$ & $; 1$ & $11+$ & \\
\hline $\begin{array}{l}\text { Steklovidnaya- } \\
24\end{array}$ & $; 2$ & $3+$ & $3+$ & $12-$ & $1+2$ & $33+$ & 3 & 3 & 12 & \\
\hline $\begin{array}{l}\text { SIETE- } \\
\text { CERROS-66 }\end{array}$ & $; 12$ & $3+$ & $3+$ & $3+$ & $33+$ & $3+$ & $3+$ & $3+$ & $3+$ & \\
\hline $\begin{array}{l}\text { Krasnodarskaya- } \\
99\end{array}$ & $2+3$ & $3+$ & $3+$ & $33+$ & $2+3$ & $3+$ & $3+$ & $3+$ & $3+$ & \\
\hline Jayhun & $3+$ & $33+$ & $3+$ & $3+$ & ; & $3+$ & $3+$ & $3+$ & $3+$ & \\
\hline IZ-80 & $33+$ & $3+$ & $; 1$ & $33+$ & 3 & 3 & ; & $3+$ & $11+$ & \\
\hline AIKT-20 & 0 & 0 & 3 & 2 & ; & ; & ; & ; & ; & \\
\hline $\begin{array}{l}\text { OTUS TOBA } \\
97\end{array}$ & ; & $; 12-$ & ; & $; 1$ & $; 1-$ & ; & ; & $33+$ & $; 1-$ & Lr16, Lr26 \\
\hline $\begin{array}{r}\text { PASTOR/3/ } \\
\text { VORONA }\end{array}$ & ; & $; 12$ & ; & $; 1$ & $; 1-$ & $; 1-$ & 3 & ; & $11+$ & \\
\hline $\begin{array}{l}\text { CMN82A.1294/ } \\
2 *\end{array}$ & ; & $; 12$ & ; & $; 1+$ & $; 1-$ & $; 11+$ & 3 & $33+$ & $11+$ & \\
\hline HUAVUN INIA & ; & $; 12$ & 0 & $; 12$ & ; & ; & $11+$ & $2+3$ & $; 1-$ & $\operatorname{Lr} 16$ \\
\hline Trakua Hatti & $; 2-$ & 2 & $3+$ & 3 & $2+3$ & $2+3$ & $33+$ & $3+$ & $11+2-$ & \\
\hline Murodi-2013 & ; & $; 1+$ & $; 12$ & 12 & $12+$ & $12+$ & $33+$ & ; & $1+2$ & \\
\hline
\end{tabular}


Table 7 continued

\begin{tabular}{|c|c|c|c|c|c|c|c|c|c|c|}
\hline \multirow[t]{2}{*}{ Accession } & \multicolumn{9}{|c|}{$L r$ seedling resistance } & \multirow[b]{2}{*}{$\begin{array}{l}\text { Lr gene } \\
\text { postulation based } \\
\text { on seedling and } \\
\text { molecular } \\
\text { marker }\end{array}$} \\
\hline & TDBGG & TFBJQ & TNRJJ & MLDSD & MBDSB & TBBGJ & KFBJG & MHDSB & TCRKG & \\
\hline $\begin{array}{l}\text { CHEN/AE.SQ// } \\
\text { WEAVER/3/ } \\
\text { PASTOR }\end{array}$ & $; 1$ & $22+$ & 3 & 3 & $33+$ & $33+$ & $33+$ & $33+$ & 12 & \\
\hline Ganj & ; & $22+$ & $; 1$ & $11+$ & $; 1$ & $; 1$ & ; & ; & $; 1-$ & \\
\hline $\begin{array}{l}\text { NAC/TH.AC// } \\
3 * \mathrm{PVN} / 3 / \\
\text { MIRL }\end{array}$ & ; & $22+$ & ; & $11+$ & $; 1$ & $; 1$ & ; & ; & $; 1-$ & \\
\hline Safedaki Pomir & 3 & $2+$ & & $; 1$ & & & $3+$ & & $3+$ & \\
\hline $\begin{array}{l}\text { Safedaki } \\
\text { Ishkoshim }\end{array}$ & & & & $1+$ & & & $3+$ & $3+$ & & \\
\hline Babilo Pomir & & & & & & & & & & Not tested \\
\hline
\end{tabular}

Molecular marker analysis for Lr26 is presented in Table 8

Accessions exhibiting infection types of; 0 to $2+$ were classified as resistant and those exhibiting $3-4$ were classified as susceptible at the seedling stage

(120 bp), which is linked to the $S r 2 / Y r 30 / L r 27$ pleiotropic resistance gene, was amplified in 25 accessions with the $P B C$ phenotype (score 1-3) (Table 8). Markers XcsSr2 (172 bp) and wMAS000005 did not detect the presence of $\mathrm{Sr} 2 /$ Yr30/Lr27 in any accessions, while marker Xgwm533 detected its presence in all accessions with the $P B C$ phenotype (score 1-3) (Table 8). Initially, all accessions with and without the LTN phenotype (score 0-3) were screened with the $\operatorname{csLV} 34$ (150 bp) marker. In thirteen cases, this marker indicated the presence of the $L r 34 / Y r 18 / S r 57$ APR resistance genes, which were subsequently validated by the wMAS000003 Kompetitive Allele Specific PCR (KASP) marker (Table 8). Use of KASP marker wMASO00005 positively detected the presence of $S r 2 / Y r 30 / L r 27$ in Hope and CS-Hope DS 3B, but failed to do so in the Tajik accessions; thus, this KASP marker is located in the "Hope and CS Hope DS 3B" allele. The Xwmc364 (207 bp) marker was used on all accessions to detect the presence of $Y r 2$, but all of them amplified a $201 \mathrm{bp}$ marker allele, indicating the absence of $\mathrm{Yr} 2$.

\section{Discussion}

In this study, we identified the presence of majoreffect (seedling) and pleiotropic APR genes conferring resistance against three important rust diseases, i.e. stem rust, stripe rust and leaf rust pathogens in wheat cultivars, landraces and advanced breeding lines that are widely cultivated and used in the national wheat breeding program in Tajikistan. The major-effect resistance genes identified by seedling and adult plant responses, and molecular marker analysis were $\mathrm{Sr} 5$, Sr6, Sr11, Sr31/Yr9/Lr26, Sr38/Yr17/Lr37, Yr27, and Lr16. Additionally, the pleiotropic APR genes of $\mathrm{Sr} 2 /$ Yr30/Lr27 and Lr34/Yr18/Sr57 were also identified based on the $P B C$ and $L T N$ phenotypes in the field and confirmed with linked molecular markers. The APR gene $\operatorname{Lr37}$ was detected by a molecular marker (VENTRIUP/LN2), which is completely linked with the $S r 38 / Y r 17$ genes. In addition, pedigree information (http://wheatpedigree.net/) also was used to augment gene postulation data. A number of the wheat accessions showed resistance to all races of the three rusts used in this study, and their infection type pattern did not correspond to the avirulence/virulence profiles of the races as identified on the differential accessions. Therefore, the resistance genes present in these accessions could not be postulated. We conclude that 


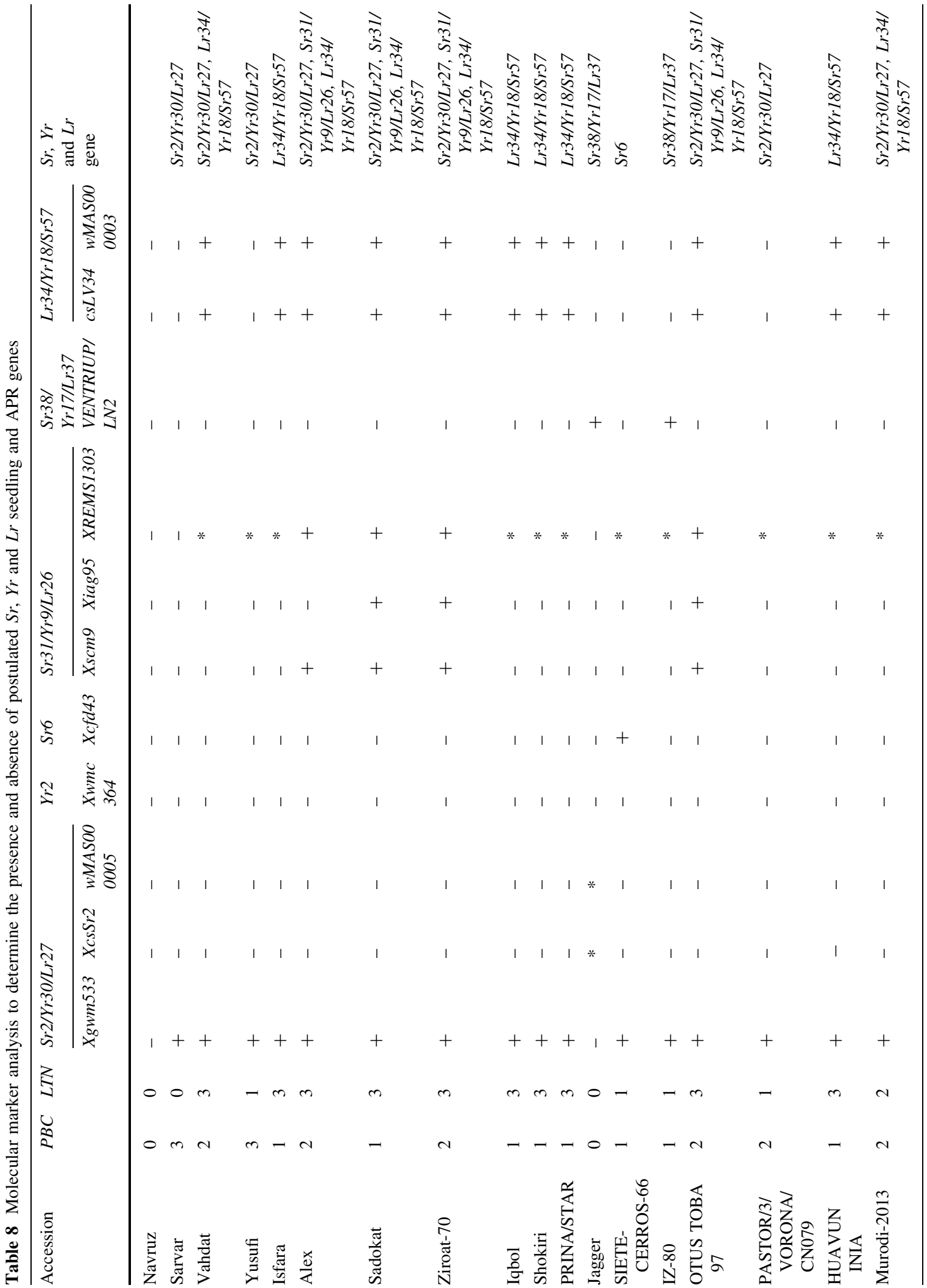




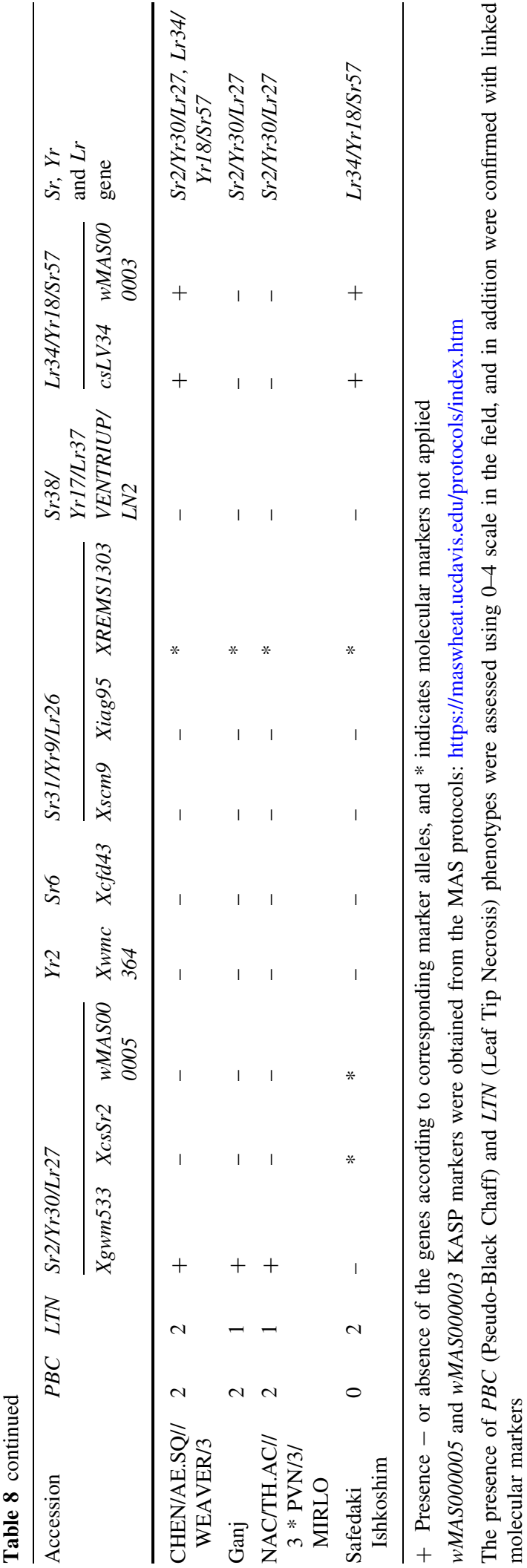

these accessions carry previously described gene(s) in combinations or new genes. To elucidate the genetic basis of resistance in these widely resistant accessions, biparental crosses, allelism tests and/or additional phenotyping tests with a wider array of rust races should be implemented ( $\mathrm{Li}$ et al. 2015; Randhawa et al. 2015). The resistance gene $\mathrm{Sr} 5$ in Navruz and $\mathrm{Sr} 6$ and $\mathrm{Sr} 11$ in Siete-Cerros-66 were identified in this investigation. Navruz is commonly used as a control in all wheat breeding nurseries and official trials (Husenov et al., 2015), and Siete-Cerros-66 has been cultivated by Tajik farmers since 1970 (Muminjanov et al. 2008). Sr5, Sr6, and Srl1 have been effective and valuable stem rust resistance genes; however, $P g t$ races with virulence for these genes are spreading in many wheat growing regions worldwide (Singh et al. 2015). Combinations of seedling and APR genes (i.e. Sr2/Yr30/Lr27, Sr31/Yr9/Lr26, Lr34/Yr18/Sr57, Lr16 etc.) were also present in some of the accessions (Table 8), thus being promising sources for improved resistance to rusts in Tajik breeding programs. Gene pyramiding using the pleiotropic APR genes of $\mathrm{Sr} 2 /$ Yr30/Lr27 and Lr34/Yrl8/Sr57 in a combination with seedling resistance genes in several wheat breeding programs has provided durable rust resistance (Ellis et al. 2014).

Four wheat accessions (Alex, Sadokat, Ziroat-70 and Otus Toba 97) were identified as carrying the Sr31/Yr9/Lr26 resistance genes. Accessions possessing this gene complex are known to have the 1BL.1RS wheat-rye translocation, originating from Petkus rye (Friebe et al. 1996). The Sr31/Yr9/Lr26 complex is very common in wheat accession due to the wide utilization of the wheat cultivars Kavkaz and Aurora in CIMMYT breeding programs worldwide (Rajaram et al. 1983). The individual genes in this complex have been overcome by virulent races of $P g t, P$ st and $P t$, respectively, in various wheat growing regions (Pretorius et al. 2000; Chen et al. 2010; Huerta-Espino et al. 2011; Wellings 2011). Sr31 has provided durable resistance to stem rust for more than 30 years, and still remains an effective source of resistance to many $\mathrm{Pgt}$ races with the exception of those in the Ug99 race group. Races of $P s t$ with virulence for $Y r 9$ have been reported from all major wheat production areas in Tajikistan based on trap nurseries and race surveys (http://wheatrust.org/). Additionally, virulence against the leaf rust resistance gene Lr26 is common in Tajikistan (Kolmer and Ordoñez 2007) and many 
other parts of the world. Thus, although the resistance genes on the 1BL.1RS translocation do not confer a high degree of resistance towards new races of the rust pathogens, wheat accessions carrying this translocation are cultivated throughout the country. Two wheat cultivars widely cultivated in Tajikistan (Jagger and IZ-80) were identified as possessing the $\mathrm{Sr} 38 / \mathrm{Yr} 17 /$ Lr37 gene complex. Previous studies have characterized the $S r 38 / Y r 17 / L r 37$ locus as a translocation of chromosome 2NS from Triticum ventricosum replacing the homoeologous region of $2 \mathrm{AS}$ in Triticum aestivum; thus, this translocation confers resistance against a range of races of $P g t$, Pst and Pt (Helguera et al. 2003). The presence of $Y r 27$ in Isfara and Lrl6 in Iqbol, OTUS TOBA 97 and Murodi-2013 were postulated. Lrl6 is known as an effective source of leaf rust resistance in wheat (Kolmer and Hughes 2013) and should provide stable resistance when pyramided with $L r 27, L r 34$, and $L r 37$ in the Tajik breeding program for the developing resistant wheat cultivar.

Both phenotyping (using $0-4$ scale for the $P B C$ phenotype) and genotyping (using the Xgwm533, $X c s S r 2$, and $w M A S 000005$ markers) were applied for detection of the $S r 2 / Y r 30 / L r 27$ APR genes; thus, only 25 accessions with the Xgwm533 marker (score 1-3 for the $P B C$ phenotype) were identified. However, only eleven accessions were considered to truly possess the $S r 2 / Y r 30 / L r 27$ APR genes based on the $X g w m 533$ marker and $P B C$ phenotype, i.e. score of 2 for medium pigmentation and 3 for high pigmentation (Table 8). The $P B C$ phenotype is known to be associated with the Sr2/Yr30/Lr27 gene complex, although its expression is sometimes variable due to both the genotype and environment (McFadden 1930). In addition, the $P B C$ phenotype is genetically associated with several quantitative trait loci (QTL) on the chromosome arms 2DS, 3BS, 4AL, and 7DS (Juliana et al. 2015). With respect to the molecular markers in the present study, XcsSr2 and wMAS000005 were only able to identify the $S r 2 / Y r 30 / L r 27$ APR genes in the Hope and CS-Hope DS 3B lines, while the Xgwm533 marker positively detected the gene complex in 25 accessions. These results corroborate previous investigations that showed no perfect match between amplification of the XcsSr2/wMAS000005 and $\mathrm{Xg}$ wm533 markers in various accessions (Mago et al. 2011; Pretorius et al. 2012). Thus, in the present study, the $P B C$ phenotype, with scores of $1-3$ in 25 accessions, showed a high degree of correlation with amplification of the Xgwm533 marker. However, the Xgwm533 marker may also positively amplify even when $\mathrm{Sr} 2 / \mathrm{Yr} 30 / \mathrm{Lr} 27$ is not present in certain wheat accessions (Spielmeyer et al. 2003; Mago et al. 2011). Hope and CS-Hope DS 3B (172 bp) have been shown to carry $\operatorname{Sr} 2 / \mathrm{Yr} 30 / \mathrm{Lr} 27$ based on studies using the $X c s S r 2$ marker (Mago et al. 2011). Initially, Sr2 was reported to be linked with the $P B C$ phenotype in the cultivar Hope; thus, this phenotypic trait has become a valuable selection trait for wheat breeders in the field (McFadden 1930). The KASP marker wMAS000005 identified the allele in Hope and CS-Hope DS 3B, thereby identifying the presence of $\mathrm{Sr} 2 / \mathrm{Yr} 30 / \mathrm{Lr} 27$. However, this marker failed to amplify any signal in the Tajik wheat, thus indicating the absence of Sr2/ Yr30/Lr27. Molecular markers csLV34 and $w M A S 000003$ successfully identified the presence of the $L r 34 / Y r 18 / S r 57$ APR genes in 13 accessions; therefore, these markers can be reliably used with $L T N$ phenotype for assessing APR genes. In addition to gene postulation, the Xwmc364 marker can be used to confirm the presence or absence of $Y r 2$ gene. This Xwmc364 (207 bp) marker positively confirmed $Y r 2$ in the Kalyansona and Heines VII differential accessions, but amplified the $201 \mathrm{bp}$ or null allele in all of the Tajik accessions, suggesting the absence of $\mathrm{Yr} 2$.

In this study, we demonstrated that some of the evaluated accessions carry seedling and pleiotropic APR resistance genes against all the used rust races. Thereby, our results show that some of the wheat accessions may be used as a diverse source of rust resistance. The gene postulation, together with the use of molecular markers, successfully applied to detect the presence of known seedling and APR genes in some of the evaluated accessions. Moreover, the genetic basis of resistance in some accessions should be characterized through other genetic analyses because gene postulation and molecular markers failed to do so in this study. In the meantime, these accessions can be used by the national wheat breeding program in Tajikistan as crossing parents to develop new varieties with durable rust resistance.

Acknowledgment Funding from the Monsanto's BeachellBorlaug International Scholars is gratefully acknowledged. We thank Kenyan Agricultural and Livestock Research Organization Food Crops Research Center and CIMMYTKenya for conducting stem rust field screenings in Kenya, Njoro. The authors appreciate Dr. James Kolmer for his 
supervision in the leaf rust seedling resistance test at USDAARS-CDL.

Author's contribution MR designed the study and was responsible for conducting all experiments. MO and HM developed some of the wheat accessions and provided seeds. MNR and BJS supervised the stem rust seedling and adult plant tests in the University of Minnesota and USDA-ARS-CDL in USA. MSH supervised the stripe rust seedling test in the GRRC in Denmark. KN supervised the stem rust and stripe rust seedling and adult plant tests in the RCRRC in Turkey. MNR, BJS, and EJ supervised the overall study. MR wrote the manuscript and all authors contributed to writing and editing the manuscript.

\section{Compliance with ethical standards}

Conflict of interest All authors have no conflict of interest.

Open Access This article is distributed under the terms of the Creative Commons Attribution 4.0 International License (http:// creativecommons.org/licenses/by/4.0/), which permits unrestricted use, distribution, and reproduction in any medium, provided you give appropriate credit to the original author(s) and the source, provide a link to the Creative Commons license, and indicate if changes were made.

\section{References}

Ali S, Rodriguez-Algaba J, Thach T, Sørensen CK, Hansen JG, Lassen P, Nazari K, Hodson DP, Justesen AF, Hovmøller MS (2017) Yellow rust epidemics worldwide were caused by pathogen races from divergent genetic lineages. Front Plant Sci 8:1-14. https://doi.org/10.3389/fpls.2017.01057

Berlin A, Rahmatov M, Muminjanov H, Yuen J (2015) Sexual reproduction contributes to genotypic variation in the population of Puccinia graminis in Tajikistan. Eur J Plant Pathol 141:159-168

Chen XM (2005) Epidemiology and control of stripe rust [Puccinia striiformis f. sp. tritici] on wheat. Can J Plant Pathol 27:314-337

Chen X, Penman L, Wan A, Cheng P (2010) Virulence races of Puccinia striiformis f. sp. tritici in 2006 and 2007 and development of wheat stripe rust and distributions, dynamics, and evolutionary relationships of races from 2000 to 2007 in the United States. Can J Plant Pathol 32:315-333

Davlatov SK, Baikova EV (2011) Altitudinal limits of Berberis L. in Tajikistan. Contemp Probl Ecol 4:164-166

Edwards K, Johnstone C, Thompson C (1991) A simple and rapid method for the preparation of plant genomic DNA for PCR analysis. Nucleic Acids Res 19:1349

Ellis JG, Lagudah E, Spielmeyer W, Dodds P (2014) The past, present and future of breeding rust resistant wheat. Front Plant Sci 5:1-13. https://doi.org/10.3389/fpls.2014.00641

Eshonova Z, Morgounov A, Paroda R, Qosymov F, Khusaynov I, Yurov A, Naimov S, Hikmatov N, Muminjanoy H (2005) Wheat breeding and seed production in different ecological zones of Tajikistan. In: Morgounov A, McNab A,
Campbell KG, Paroda R (eds) Increasing wheat production in Central Asia through science and cooperation. Proceedings of the first Central Asian wheat conference, 10-13 June 2003, Almaty. CIMMYT, pp 58-61

FAO (2015) Wheat Landraces in farmers' fields in Tajikistan: National survey, collection, and conservation, 2013-2015. In: Husenov B, Otambekova M, Morgounov A, Muminjanov H. Ankara, Turkey. http://www.fao.org/3/a-i5187e. pdf. Accessed 19 Feb 2019

Flor HH (1971) Current status of the gene-for-gene concept. Ann Rev Phytopathol 9:275-296

Friebe B, Jiang J, Raupp WJ, McIntosh RA, Gill BS (1996) Characterization of wheat-alien translocations conferring resistance to diseases and pests: current status. Euphytica 91:59-87

Helguera M, Khan IA, Kolmer J, Lijavetzky D, Zhong-qi L, Dubcovsky J (2003) PCR Assays for the Lr37-Yr17-Sr38 cluster of rust resistance genes and their use to develop isogenic hard red spring wheat lines. Crop Sci 43:1839-1847

Hovmøller MS, Sørensen CK, Walter S, Justesen AF (2011) Diversity of Puccinia striiformis on cereals and grasses. Ann Rev Phytopathol 49:197-217

Hovmøller MS, Rodriguez-Algaba J, Thach T, Sørensen CK (2017) Race typing of Puccinia striiformis on wheat. In: Periyannan S (ed) Wheat rust diseases: methods and protocols. Springer, New York, pp 29-40

Huerta-Espino J, Singh RP, Germán S, McCallum BD, Park RF, Chen WQ, Bhardwaj SC, Goyeau H (2011) Global status of wheat leaf rust caused by Puccinia triticina. Euphytica 179:143-160

Husenov B, Makhkamov M, Garkava-Gustavsson L, Muminjanov H, Johansson E (2015) Breeding for wheat quality to assure food security of a staple crop: the case study of Tajikistan. Agric Food Secur 4:1-8

Jin Y, Singh RP, Ward RW, Wanyera R, Kinyua M, Njau P, Fetch T, Pretorius ZA, Yahyaoui A (2007) Characterization of seedling infection types and adult plant infection responses of monogenic $S r$ gene lines to race TTKS of Puccinia graminis f. sp. tritici. Plant Dis 91:1096-1099

Juliana P, Rutkoski JE, Poland JA, Singh RP, Murugasamy S, Natesan S, Barbier H, Sorrells ME (2015) Genome-wide association mapping for leaf tip necrosis and pseudo-black chaff in relation to durable rust resistance in wheat. Plant Genome 8:1-12

Juliana P, Singh RP, Singh PK, Crossa J, Huerta-Espino J, Lan C, Bhavani S, Rutkoski JE, Poland JA, Bergstrom GC, Sorrells ME (2017) Genomic and pedigree-based prediction for leaf, stem, and stripe rust resistance in wheat. Theor Appl Genet 130:1415-1430

Knott (1989) Breeding methods. In: Frankel R, Grossman M, Linskens HF, Maliga P, Riley R (eds) The wheat rustsbreeding for resistance, vol 12. Monographs on theor appl gen. Springer, Berlin, Heidelberg, pp 126-148

Kolmer JA (2005) Tracking wheat rust on a continental scale. Curr Opin Plant Biol 8:441-449

Kolmer JA, Hughes ME (2013) Physiologic specialization of Puccinia triticina on wheat in the United States in 2011. Plant Dis 97:1103-1108 
Kolmer JA, Ordoñez ME (2007) Genetic differentiation of Puccinia triticina populations in Central Asia and the Caucasus. Phytopathology 97:1141-1149

Lagudah ES, McFadden H, Singh RP, Huerta-Espino J, Bariana HS, Spielmeyer W (2006) Molecular genetic characterization of the Lr34/Yr18 slow rusting resistance gene region in wheat. Theor App Genet 114:21-30

Li H, Vikram P, Singh RP, Kilian A, Carling J, Song J, Burgueno-Ferreira JA, Bhavani S, Huerta-Espino J, Payne T, Sehgal D, Wenzl P, Singh S (2015) A high density GBS map of bread wheat and its application for dissecting complex disease resistance traits. BMC Genom 16:1-15

Lin F, Xu SC, Zhang LJ, Miao Q, Zhai Q, Li N (2005) SSR marker of wheat stripe rust resistance gene $Y r 2$. J Triticeae Crops 25:17-19 (in Chinese with an English abstract)

Long DL, Kolmer JA (1989) A North American system of nomenclature for Puccinia recondita f. sp. tritici. Phytopathology 79:525-529

Mago R, Miah H, Lawrence GJ, Wellings CR, Spielmeyer W, Bariana HS, McIntosh RA, Pryor AJ, Ellis JG (2005) Highresolution mapping and mutation analysis separate the rust resistance genes $\operatorname{Sr} 31, \operatorname{Lr} 26$ and $\mathrm{Yr} 9$ on the short arm of rye chromosome 1. Theor Appl Genet 112:41-50

Mago R, Brown-Guedira G, Dreisigacker S, Breen J, Jin Y, Singh R, Appels R, Lagudah ES, Ellis J, Spielmeyer W (2011) An accurate DNA marker assay for stem rust resistance gene $\mathrm{Sr} 2$ in wheat. Theor Appl Genet 122:735-744

McFadden ES (1930) A successful transfer of emmer characters to vulgare wheat. J Am Soc Agron 22:1020-1034

McIntosh RA, Dubcovsky J, Rogers WJ, Morris C, Xia XC (2017) Catalogue of gene symbols for wheat: 2017 supplement. https://shigen.nig.ac.jp/wheat/komugi/genes/ macgene/supplement2017.pdf. Accessed 19 Feb 2019

McNeal FH, Konzac CF, Smith EP, Tate WS, Russell TS (1971) A uniform system for recording and processing cereal research data. ARS-USDA, Washington, pp 34-121

Muminjanov H, Eshonova Z, Morgounov A (2008) Wheat yield potential improvement in Tajikistan. In: Reynolds MP, Pietragalla J, and Braun H-J (eds) Challenges to international wheat breeding. Proceedings of the international symposium on wheat yield potential, 20-24 Mar 2006, Obregon. CIMMYT, pp 87-90

Oelke LM, Kolmer JA (2004) Characterization of leaf rust resistance in hard red spring wheat cultivars. Plant Dis 88:1127-1133

Peterson RF, Campbell AB, Hannah AE (1948) A diagrammatic scale for estimating rust severity on leaves and stems of cereals. Can J Res 26:496-500

Pett B, Muminjanov H, Morgunov A, Rahmatov M, Sarkisova T (2005) Wheat diseases \& pests observation for selection of resistant varieties in Tajikistan. Agromeridian Theor Appl Agric Res J 1:83-87

Pretorius ZA, Singh RP, Wagoire WW, Payne TS (2000) Detection of virulence to wheat stem rust resistance gene Sr31 in Puccinia graminis. f. sp. tritici in Uganda. Plant Dis $84: 203$

Pretorius ZA, Jin Y, Bender CM, Herselman L, Prins R (2012) Seedling resistance to stem rust race $\mathrm{Ug} 99$ and marker analysis for $\mathrm{Sr} 2, \mathrm{Sr} 24$ and $\mathrm{Sr} 31$ in South African wheat cultivars and lines. Euphytica 186:15-23
Rahmatov M, Muminjanov H, Eshonova Z, Morgounov A, Hede A, Johansson E (2011) The national wheat breeding program for development of high yielding and rusts resistant of bread wheats for Tajikistan. In: McIntosh R, Proceedings of the Borlaug global rust initiative technical workshop, 11-16 June 2011, St Paul, p 174

Rahmatov M, Eshonova Z, Ibrogimov A, Otambekova M, Khuseinov B, Muminjanov H, Morgounov A, Merker A, Hede A (2012) Monitoring and evaluation of yellow rust for breeding resistant varieties of wheat in Tajikistan. In: Yahyaoui A, Rajaram S (eds) Meeting the challenge of yellow rust in cereal crops. Proceedings of the $2 \mathrm{nd}$, 3rd and 4th regional conferences on yellow rust in the Central and West Asia and North Africa (CWANA) region, 10-12 Oct 2009, Antalya. ICARDA, pp 318-325

Rahmatov M, Rouse MN, Steffenson BJ, Andersson SC, Wanyera R, Pretorius ZA, Houben A, Kumarse N, Bhavani S, Johansson E (2016) Sources of stem rust resistance in wheat-alien introgression lines. Plant Dis 100:1101-1109

Rahmatov M, Hovmøller MS, Nazari K, Andersson SC, Steffenson BJ, Johansson E (2017) Seedling and adult plant stripe rust resistance in diverse wheat-alien introgression lines. Crop Sci 57:2032-2042

Rajaram S, Mann CE, Ortiz-Ferrara G, Mujeeb-Kazi A (1983) Adaptation, stability and high yield potential of certain 1B/ 1R CIMMYT wheats. In: Sakamoto S (ed) Proceedings of the 6th international wheat genetic symposium, Kyoto, pp 613-621

Randhawa MS, Bariana HS, Mago R, Bansal UK (2015) Mapping of a new stripe rust resistance locus $\operatorname{Yr} 57$ on chromosome 3BS of wheat. Mol Breed 35:1-8

Roelfs AP, Singh RP, Saari EE (1992) Rust diseases of wheat: concepts and methods of disease management. CIMMYT, Mexico

Rouse MN, Wanyera R, Njau P, Jin Y (2011) Sources of resistance to stem rust race $\mathrm{Ug} 99$ in spring wheat germplasm. Plant Dis 95:762-766

Saal B, Wricke G (1999) Development of simple sequence repeat markers in rye (Secale cereale L.). Genome 42:964-972

Shiferaw B, Smale M, Braun H-J, Duveiller E, Reynolds M, Muricho G (2013) Crops that feed the world 10. Past successes and future challenges to the role played by wheat in global food security. Food Secur 5:291-317

Singh RP, Hodson DP, Jin Y, Lagudah ES, Ayliffe MA, Bhavani S, Rouse MN, Pretorius ZA, Szabo LJ, Huerta-Espino J, Basnet BR, Lan C, Hovmøller MS (2015) Emergence and spread of new races of wheat stem rust fungus: continued threat to food security and prospects of genetic control. Phytopathology 105:872-884

Solh M, Nazari K, Tadesse W, Wellings C (2012) The growing threat of stripe rust worldwide. In: McIntosh R (ed) Proceedings of the Borlaug global rust initiative technical workshop, 1-4 Sept 2012, Beijing, pp 1-10

Spielmeyer W, Sharp PJ, Lagudah ES (2003) Identification and validation of markers linked to broad-spectrum stem rust resistance gene $\mathrm{Sr} 2$ in wheat (Triticum aestivum L.). Crop Sci 43:333-336

Stakman EC, Stewart DM, Loegering WQ (1962) Identification of physiologic races of Puccinia graminis var. tritici. 
United States Department of Agriculture, Agricultural Research Service, Beltsville, p E-617

Szabo L, Cuomo C, Park R (2014) Puccinia graminis. In: Dean RA, Lichens-Park A, Kole C (eds) Genomics of plant-associated fungi: monocot pathogens. Springer, Berlin, Heidelberg, pp 177-196

Tsilo TJ, Chao S, Jin Y, Anderson AJ (2009) Identification and validation of SSR markers linked to the stem rust resistance gene $\operatorname{Sr} 6$ on the short arm of chromosome 2D in wheat. Theor Appl Gen 118:515-524

Wellings C (2011) Global status of stripe rust: a review of historical and current threats. Euphytica 179:129-141

Yahyaoui A, El Ahmed M, Naimi M, Ketata H, Morgounov A, Torabi M, Cetin L, Saidov M, Koyshibaev M, Djunusova M (2012a) Prevalent yellow rust pathotypes in CWANA. In: Yahyaoui A, Rajaram S (eds) Meeting the challenge of yellow rust in cereal crops. Proceedings of the $2 \mathrm{nd}$, 3rd and 4 th regional conferences on yellow rust in the Central and
West Asia and North Africa (CWANA) region, 22-26 Mar 2004, Islamabad. ICARDA, pp 137-138

Yahyaoui A, Ketata H, Torabi M, Morgounov A, Braun H, Mosaad M, Djumakhanov B, Koichibayev M (2012b) Cereal rust monitoring in Central and West Asia and North Africa: current status and future challenges. In: Yahyaoui A, Rajaram S (eds) Meeting the challenge of yellow rust in cereal crops. Proceedings of the 2nd, 3rd and 4th regional conferences on yellow rust in the Central and West Asia and North Africa (CWANA) Region, 22-26 Mar 2004, Islamabad, Pakistan. ICARDA, pp 155-170

Zadoks JC, Chang TT, Konzak CF (1974) A decimal code for the growth stages of cereals. Weed Res 14:415-421

Publisher's Note Springer Nature remains neutral with regard to jurisdictional claims in published maps and institutional affiliations. 